\title{
PERANCANGAN SISTEM PAKAR UNTUK MENENTUKAN KELAS PADA ANAK BERKEBUTUHAN KHUSUS DENGAN METODE FORDWARD CHAINING
}

\author{
Yulvia Nora Marlim ${ }^{1}$.Wahyu Joni Kurniawan ${ }^{2}$ \\ ${ }^{1,2}$ Sekolah Tinggi Ilmu Komputer Pelita Indonesia, Jln Ahmad Yani 78-88 Pekanbaru \\ email: ${ }^{1}$ yulvia.nora@lecturer.pelitaindonesia.ac.id, ${ }^{2}$ wahyu.jonikurniawan@lecturer.pelitaindonesia.ac.id
}

\begin{abstract}
Abstract: Children with special needs are different children in general. Included in children with special needs include: blind, deaf, mentally disabled, physically disabled, tuna, learning difficulties, behavioral disorders, gifted children and children experiencing health problems. Teachers at Extraordinary School Negri Pembina Pekanbaru experienced limitations in determining the class for the child. This study aims to design a system for teaching staff to place children of children with special class needs based on symptomatic symptoms that appear with the search technique using the forward chaining method. Forward Chaining is a search method or tracking technique that starts with information that has a merging rule to produce a conclusion or goal. This expert system will display questions that will then be selected by the user to find answers from the system. It is hoped that by implementing this expert system it will help teaching staff to determine the type of developmental disorders of children with special needs to place them in the right class, without any dissent.
\end{abstract}

Keywords: Expert System, Children with Special Needs, Forward Chaining, Teachers, Class Determination.

\begin{abstract}
Abstrak
Anak berkebutuhan khusus (ABK) adalah anak yang memerlukan perhatian kusus dari anak-anak normal. Yang termasuk dalam anak berkebutuhan khusus antara lain: tuna netra, tuna rungu, tuna grahita, tuna daksa, tuna laras, kesulitan belajar,gangguan prilaku, anak berbakat dan anak mengalami gangguan kesehatan. Tenaga pengajar pada SLB (Sekolah Luar Biasa) Negri Pembina Pekanbaru mengalami keterbatasan dalam menentukan kelas pada anak berkebutuhan. Penelitian ini bertujuan merancang sebuah sistem untuk tenaga pengajar guna menempatkan anak anak berkebutuhan khusus kekelas yang tepat berdasarkan gejala gejala yang tampak dengan teknik penelusuran menggunakan metode forward chaining. Forward Chaining adalah metode pencarian pelacakan dimulai dengan informasi yang ada penggabungan rule untuk menghasilkan suatu kesimpulan atau tujuan. Sistem pakar ini akan menampilkan pertanyaan yang kemudian akan dipilih oleh user sampai menemukan jawaban dari sistem. Diharapkan dengan diterapkan sistem pakar ini membantu tenaga pengajar untuk menentukan jenis gangguan perkembangan anak berkebutuhan khusus guna menempatkan mereka pada kelas yang tepat, tanpa adanya perbedaan pendapat.
\end{abstract}

Kata Kunci: Sistem Pakar, Anak berkebutuhan Khusus, Forward chaining,Tenaga Pengajar, penentuan kelas.

\section{PENDAHULUAN}

Memasuki era revolusi industri 4.0 mendorong setiap peneliti dalam mengembangkan ilmu komputer. Komputer tidak dapat dilepaskan peranannya dalam berbagai bidang, seperti dalam bilang pendidikan, bisnis, industri, kesehatan dan entertainment. Perkembangan komputer ini bertujuan untuk membantu pekerjaan manusia (Rohman, 2008)

Kemampuan dari kecerdasan buatan adalah menuangkan pengetahuan pakar ke sebuah sistem dan dapat melakukan pekerjaan seperti dan sebaik yang dilakukan manusia (William P.Wagner 2017). Intelligent system dikatakan sebagai sistem yang dibuat dengan mengunakan teknik- 
teknik artificial intelligence (A, Kristianto, 2004).

Penelitian ini di dukung oleh peneliti sebelumnya yaitu dalam menentukan (mendiagnosa) penyakit paru-paru kronis yang diderita oleh bayi secara dini (Ochab, Marcin,2016)

Sistem pakar juga digunakan dibidang psikologi. Salah satu nya adalah untuk menentukan gangguan pekembangan pada anak yang berkebutuhan khusus guna menentukan tingkatan kelas mereka.

Anak berkebutuhan khusus (ABK) adalah anak yang memerlukan perhatian khusus dan tanpa selalu menunjukan kemampuan mental, emosi atau fisik. Yang tergolong kedalam ABK (Anak Berkebutuhan khusus) antara lain : tuna netra, tuna rungu, tuna grahita, tuna daksa, tuna laras, kesulitan belajar, gangguan prilaku, anak berbakat dan anak gangguan kesehatan (Ochab, Marcin,2016). SLB (Sekolah Luar Biasa) Negri Pembina Pekanbaru merupakan Instusi pendidikan yang bergerak dibidang pendidikan anak berkebutuhan khusus. Jenjang pendidikan di SLB(Sekolah Luar Biasa) Negri Pembina Pekanbaru mulai dari TKLB, SDLB, SMPLB, dan SMALB. Jumlah pengajar yang ada pada SLB (Sekolah Luar Biasa) ini adalah 15 orang tenaga pengajar data ini penulis dapatkan berdasarkan hasil observasi ke lapangan pada bulan September tahun 2018, dengan keterbatasan tenaga pengajar yang ahli dalam menentukan jenis gangguan anak, guru mengalami kendala dalam melayani orang tua murid yang ingin berkonsultasi mengenai penempatan kelas pada anak mereka pada saat pendaftaran sekolah.

Dan belum adanya metode yang diterapkan untuk menentukan gejala-gejala anak berkebutuhan khusus, mengakibatkan penentuan kelas hanya berdasarkan pengalaman dan pengetahuan yang dimiliki oleh tenaga pengajar saja. Dimana pengetahuan dan pendapat yang dimiliki oleh tenaga pengajar tersebut berbeda-beda. Sehingga sering terjadi kesalahan dan perbedaan pendapat dalam penentuan kelas. Dengan ini mengakibatkan murid-murid kesulitan dalam menerima pelajaran yang disampaikan.

Dari uraian permasalahan diatas maka peneliti tertarik menerapkan system pakar dalam menentukan kelas yang tepat untuk anak-anak berkebutuhan khusus dengan menggunakan metode fordward chaining. Metode fordward chaining ini metode yang tepat dalam penelitian ini karena berdasarkan gejala-gejala yang tampak.

\section{METODE PENELITIAN}

\section{Artificial Intelligence (Kecerdasan Buatan)}

Kecerdasan buatan yakni sebuah mekanisme serta membuat komputer berfikir secara cerdas dan mekanisme pengetahuan seorang pakar yang dituangkan kedalam sistem(A, Kristianto, 2004). Kecerdasan buatan juga bisa dikatakan sebagai salah satu ilmu komputer yang menjadikan komputer untuk bisa mengerjakan pekerjaan layaknya manusia(Kusrini, 2006).

Bidang ini dapat dipelajari di bidangbidang, seperti : Neural Network, Pengenalan suara, Sistem pakar, robotika, penglihatan komputer, jaringan syaraf tiruan dan penglihatan computer (A, Kristianto, 2004).

\section{Forward Chaining}

Pelacakan kedepan (Fordward Chaining) berarti menggunakan himpunan aturan kondisi-aksi. Dalam metode ini, Data atau nama anak berkebutuhan khusus sudah diketahui. Namun yang harus ditelusuri lagi adalah gejala-gelaja yang tampak untuk menentukan kelas, apakah di SD, SMP atau di SMA. Gejala- gejala tersebut dijadikan data dan diterapkan sehingga terbentuk aturan yang akan dijalankan. Proses ini dilakukan berulang sampai ditemukan hasil (M. Arhami, 2005).

Dalam penelitian ini memiliki beberapa tahapan yaitu :

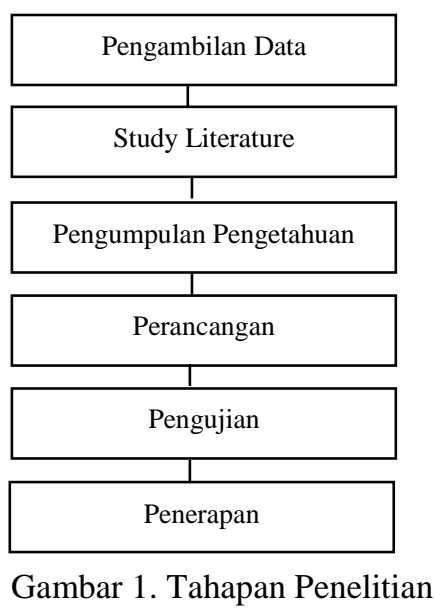




\section{HASIL DAN PEMBAHASAN}

Pada table 1 ada jenis-jenis anak berkebutuhan khusus dan tabel 2 dapat dilihat jenis-jenis gangguan pada anak berkebutuhan khusus data ini diambil dari pakar yaitu tenaga pengajar, bukubuku, artikel-artikel yang berkaitan.

\section{Pembuatan Rule Based}

Tabel 1. Data Anak Berkebutuhan Khusus

\begin{tabular}{|l|l|}
\hline KdAbk & Nama Abk \\
\hline ABK1 & Autis \\
\hline ABK2 & Tuna Grahita \\
\hline ABK3 & Tuna Rungu \\
\hline ABK4 & Tuna Netra \\
\hline ABK5 & Tuna Daksa \\
\hline
\end{tabular}

Tabel 2. Data Gangguan Anak Berkebutuhan Khusus

\begin{tabular}{|l|l|}
\hline KdGang & \multicolumn{1}{c|}{ Nama Gangguan } \\
\hline JG1 & Sindrom Asperger \\
\hline JG2 & Autistic Spectrum Disorder \\
\hline JG3 & Rett Syndrome \\
\hline JG4 & Tuna Grahita Ringan \\
\hline JG5 & Tuna Grahita Sedang \\
\hline JG6 & Tuna Grahita Berat \\
\hline JG7 & Tuna Rungu Ringan \\
\hline JG8 & Tuna Rungu Sedang \\
\hline JG9 & Tuna Rungu Berat \\
\hline JG10 & Netra Low Vision \\
\hline JG11 & $\begin{array}{l}\text { Tuna Netra setengah } \\
\text { berat/hampir buta }\end{array}$ \\
\hline JG12 & Tunanetra berat/buta total \\
\hline JG13 & Tuna Daksa \\
\hline
\end{tabular}

Tabel 3. Data Gejala-Gejala Gangguan

\begin{tabular}{|c|l|}
\hline KdGjl & \multicolumn{1}{|c|}{ Nama Gejala } \\
\hline G1 & $\begin{array}{l}\text { Memiliki masalah dengan kontak } \\
\text { mata. }\end{array}$ \\
\hline G2 & Ekspresi wajah yang tidak normal. \\
\hline G3 & $\begin{array}{l}\text { Gerakan motorik tidak terkoordinasi } \\
\text { yang meliputi postur tubuh yang } \\
\text { aneh, gaya berjalan yang kaku, atau } \\
\text { gerakan canggung. }\end{array}$ \\
\hline
\end{tabular}

\begin{tabular}{|c|c|}
\hline G4 & Terobsesi pada pengulangan. \\
\hline G5 & $\begin{array}{l}\text { Gangguan hubungan sosial dan } \\
\text { kepribadian eksentrik. }\end{array}$ \\
\hline G6 & Mengalami kesulitan berbicara. \\
\hline G7 & $\begin{array}{l}\text { Gaya bicara cenderung formal, } \\
\text { mengambil segala sesuatu secara } \\
\text { harfiah, dan tidak mampu mengenali } \\
\text { kiasan atau sindiran. }\end{array}$ \\
\hline G8 & $\begin{array}{l}\text { Sibuk dengan diri sendiri, berpikir } \\
\text { tidak fleksibel, dan kurang imajinasi. }\end{array}$ \\
\hline G9 & $\begin{array}{l}\text { Anak tida suka bergaul dengan } \\
\text { teman-temanyang menyendiri }\end{array}$ \\
\hline G10 & Sulit bersosialisasi. \\
\hline G11 & $\begin{array}{l}\text { Sulit berkomunikasi dan berinteraksi } \\
\text { dengan orang lain. }\end{array}$ \\
\hline G12 & $\begin{array}{l}\text { Memiliki pola kebiasaan yang } \\
\text { berulang. }\end{array}$ \\
\hline G13 & Keterlambatan dalam perkembangan. \\
\hline G14 & $\begin{array}{l}\text { Kehilangan tujuan gerakan tangan, } \\
\text { seperti menggenggam dengan jari, } \\
\text { mencapai sesuatu, atau menyentuh } \\
\text { sesuatu dengan sengaja. }\end{array}$ \\
\hline G15 & Kehilangan kemampuan berbicara. \\
\hline G16 & $\begin{array}{lcc}\text { Terdapat } & \text { masalah } & \text { koordinasi, } \\
\text { termasuk } & \text { kehilangan } & \text { kemampuan } \\
\text { untuk berjalan dalam banyak kasus. }\end{array}$ \\
\hline G17 & $\begin{array}{l}\text { Gerakan tangan Stereotypic, seperti } \\
\text { meremas-remas tangan. }\end{array}$ \\
\hline G18 & $\begin{array}{l}\text { Gerakan melengkung dari tulang } \\
\text { belakang yang terjadi pada sekitar } 80 \\
\text { persen. }\end{array}$ \\
\hline G19 & $\begin{array}{l}\text { Masalah makan sendiri, kesulitan } \\
\text { menelan dan mengunyah. }\end{array}$ \\
\hline G20 & $\begin{array}{l}\text { Masalah dengan tidur, khususnya } \\
\text { pola tidur terganggu di malam hari } \\
\text { dan peningkatan total tidur dan siang } \\
\text { hari. }\end{array}$ \\
\hline G21 & $\begin{array}{l}\text { Tingkat kecerdasan sekitar } 50 / 55- \\
70 / 75 \text {, dengan Mental Age (MA) } \\
\text { antara } 7-10 \text { tahun. Jadi walaupun } \\
\text { anak sudah mencapai } 12 \text { tahun, } \\
\text { kemampuan mentalnya setara dengan } \\
\text { anak normal 7-10 tahun. }\end{array}$ \\
\hline G22 & Kurang bisa berpikir logis. \\
\hline G23 & $\begin{array}{l}\text { Kurang memiliki kemampuan } \\
\text { menganalisa. }\end{array}$ \\
\hline G24 & $\begin{array}{l}\text { Kurang dapat menghubungkan } \\
\text { kejadian yang satu adegan dengan } \\
\text { yang lain. }\end{array}$ \\
\hline G25 & $\begin{array}{l}\text { Kurang dapat membedakan hal-hal } \\
\text { yang penting dan tidak penting }\end{array}$ \\
\hline G26 & Daya fantasinya sangat lemah. \\
\hline G27 & $\begin{array}{l}\text { Kurang dapat mengendalikan emosi } \\
\text { atau temperament }\end{array}$ \\
\hline G28 & $\begin{array}{l}\text { Kepribadian yang kurang harmonis, } \\
\text { anak sukar menilai baik dan buruk. }\end{array}$ \\
\hline G29 & Daya konsentrasi kurang. \\
\hline G30 & Perkembangan mentalnya lambat. \\
\hline G31 & Tingkat kecerdasan Mempunyai IQ \\
\hline
\end{tabular}




\begin{tabular}{|c|c|}
\hline & antara kisaran $30 \mathrm{~s} / \mathrm{d} 50$. \\
\hline G32 & $\begin{array}{l}\text { Kemampuan untuk mempelajari } \\
\text { bidang pelajaran akademik pada } \\
\text { tingkat dasar dan menengah sangat } \\
\text { lambat. }\end{array}$ \\
\hline G33 & $\begin{array}{l}\text { Kemampuan dalam menyelesaikan } \\
\text { masalah sosial supaya anak dapat } \\
\text { menyesuakan diri dalam masyarakat } \\
\text { juga lemah. }\end{array}$ \\
\hline G34 & $\begin{array}{l}\text { Tingkat kecerdasan Mempunyai IQ } \\
\text { dibawah } 30 .\end{array}$ \\
\hline G35 & Kematangan motorik lambat. \\
\hline G36 & $\begin{array}{l}\text { Tunagrahita berat dapat kelihatan } \\
\text { dari fisiknya. }\end{array}$ \\
\hline G37 & Koordinasi gerak kurang. \\
\hline G38 & Suka menyendiri. \\
\hline G39 & $\begin{array}{l}\text { Kemampuan mendengar masih baik } \\
\text { karena berada digaris batas antara } \\
\text { pendengaran normal atau kekurangan } \\
\text { pendengaran taraf ringan. }\end{array}$ \\
\hline G40 & $\begin{array}{l}\text { mengalami kehilangan pendengaran } \\
\text { antara } 27-40 \mathrm{DB} \text {. }\end{array}$ \\
\hline G41 & $\begin{array}{l}\text { Tidak mengalami kesulitan } \\
\text { memahami pembicaraan dan dapat } \\
\text { mengikuti sekolah biasa dengan } \\
\text { syarat tempat duduknya perlu } \\
\text { diperhatikan, teruama dekat guru. }\end{array}$ \\
\hline G42 & $\begin{array}{l}\text { Dapat belajar bicara secara efektif } \\
\text { dengan melalui kemampuan } \\
\text { pendengarannya. }\end{array}$ \\
\hline G43 & $\begin{array}{l}\text { Perlu diperhatikan kekayaan } \\
\text { pembendaharaann bahasanya supaya } \\
\text { perkembangan bicara dan bahasanya } \\
\text { tidak terhambat. }\end{array}$ \\
\hline G44 & $\begin{array}{l}\text { Dapat mengerti percakapan biasa } \\
\text { pada jarak sangat dekat. }\end{array}$ \\
\hline G45 & $\begin{array}{l}\text { Tidak mengalami kesulitan untuk } \\
\text { mengekspresikan isi hatinya. }\end{array}$ \\
\hline G46 & $\begin{array}{l}\text { Tidak dapat menangkap suatu } \\
\text { percakapan yang lemah. }\end{array}$ \\
\hline G47 & $\begin{array}{l}\text { Kesulitan menangkap isi } \\
\text { pembicaraan dari lawan jenisnya jika } \\
\text { posisinya tidak searah dengan } \\
\text { pandangannya (berhadapan). }\end{array}$ \\
\hline G48 & $\begin{array}{l}\text { Sering terjadi } \text { Miss-understanding } \\
\text { (kesalahpahaman) } \\
\text { bicaranya. }\end{array}$ \\
\hline G49 & $\begin{array}{l}\text { Pembenda arahan kosakatanya sangat } \\
\text { terbatas. }\end{array}$ \\
\hline G50 & Kesulitan membedakan suara. \\
\hline G51 & $\begin{array}{l}\text { Tidak memiliki kesadaran bahwa } \\
\text { benda-benda yang berada } \\
\text { disekitarnya mengalami getaran } \\
\text { suara. }\end{array}$ \\
\hline G52 & $\begin{array}{l}\text { Hanya dapat mendengar suara keras } \\
\text { sekali pada jarak kira-kira } 1 \text { inci } \\
( \pm 2,54 \mathrm{~cm}) .\end{array}$ \\
\hline G53 & $\begin{array}{l}\text { Biasanya ia tidak menyadari bunyi } \\
\text { keras, mungkin juga ada reaksi jika }\end{array}$ \\
\hline
\end{tabular}

\begin{tabular}{|c|c|}
\hline & dekat telinga. \\
\hline G54 & $\begin{array}{lll}\begin{array}{l}\text { Ganguan pada } \\
\text { mobilitas umum. }\end{array} & \text { orientasi dan } \\
\end{array}$ \\
\hline G55 & $\begin{array}{l}\text { Mendapat kesukaran berlalu lintas } \\
\text { dan melihat nomor mobil. }\end{array}$ \\
\hline G56 & Membaca perlu memakai lensa kuat. \\
\hline G57 & membaca menjadi lambat. \\
\hline G58 & $\begin{array}{l}\text { Jarak pandang saat membaca/melihat } \\
\text { mengalami ganguan. }\end{array}$ \\
\hline G59 & $\begin{array}{l}\text { Memiringkan kepala bila memulai } \\
\text { suatu pekerjaan. }\end{array}$ \\
\hline G60 & $\begin{array}{l}\text { Penglihatan menghitung jari kurang } \\
\text { empat kaki. }\end{array}$ \\
\hline G61 & $\begin{array}{l}\text { Kesulitan dalam menunjuk atau } \\
\text { mencari benda kecuali warnanya } \\
\text { kontrak. }\end{array}$ \\
\hline G62 & $\begin{array}{l}\text { Berjalan dengan menyeretkan atau } \\
\text { menggeserkan kaki atau salah } \\
\text { langkah. }\end{array}$ \\
\hline G63 & $\begin{array}{l}\text { Penglihatan tidak bermanfaat bagi } \\
\text { orientasi mobilitas. }\end{array}$ \\
\hline G64 & $\begin{array}{l}\text { Curiga yang berlebihan pada orang } \\
\text { lain, ini disebabkan oreh } \\
\text { kekurangmampuannya dalam } \\
\text { berorientasi terhadap lingkungannya. }\end{array}$ \\
\hline G65 & $\begin{array}{lr}\text { Mudah tersinggung, akibat } \\
\text { pengalaman-pengalaman } \\
\text { kurang menyenangkan ang } \\
\text { mengecewakan yang sering dialami, } \\
\text { menjadikan anak-anak tunanetra } \\
\text { mudah tersinggung. }\end{array}$ \\
\hline G66 & $\begin{array}{l}\text { Perhatian terpusat dimana Kebutaan } \\
\text { menyebabkan dalam melakukan } \\
\text { suatu kegiatan akan terpusat. } \\
\text { Perhatian terpusat ini sangat } \\
\text { mendukung kepekaan indera masih } \\
\text { ada. }\end{array}$ \\
\hline G67 & $\begin{array}{l}\text { Tidak mengenal adanya rangsangan } \\
\text { sinar. }\end{array}$ \\
\hline G68 & $\begin{array}{l}\text { Seluruhnya tergantung pada alat } \\
\text { indera selain mata. }\end{array}$ \\
\hline G69 & $\begin{array}{l}\text { Kordinasi atau kerjasama antara mata } \\
\text { dan anggota badan yang lemah. }\end{array}$ \\
\hline G70 & $\begin{array}{l}\text { Kesulitan melakukan gerakan yang } \\
\text { halus atau lembut. }\end{array}$ \\
\hline G71 & kecacatan pada bagian tubuh tertentu. \\
\hline G72 & $\begin{array}{l}\text { Sulit dalam melakukan suatu } \\
\text { pekerjaan/bermain. }\end{array}$ \\
\hline G73 & Lemah Fikiran. \\
\hline G74 & Terbelakang mental. \\
\hline G75 & Emosi susah dikendalikan. \\
\hline G76 & $\begin{array}{l}\text { Keterbatasan melakukan aktifitas } \\
\text { fisik. }\end{array}$ \\
\hline G77 & $\begin{array}{l}\text { Memiliki keseimbangan tubuh yang } \\
\text { lemah. }\end{array}$ \\
\hline G78 & $\begin{array}{l}\text { Mengalami Trauma dalam tingkat } \\
\text { tertentu. }\end{array}$ \\
\hline
\end{tabular}


Tabel 4. Data Pengendalian \& Terapi ABK

\begin{tabular}{|c|c|}
\hline $\begin{array}{l}\text { Kd } \\
\text { pgdl\& } \\
\text { Terapi }\end{array}$ & Nama Pengendalian \& Terapi \\
\hline PT1 & Terapi perilaku kognitif. \\
\hline PT2 & Pelatihan keterampilan sosial. \\
\hline PT3 & $\begin{array}{l}\text { Terapi wicara dan aktivitas bisa } \\
\text { membantu anak. }\end{array}$ \\
\hline PT4 & 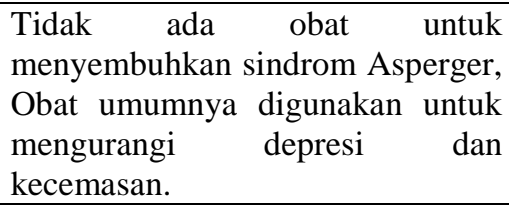 \\
\hline PT5 & $\begin{array}{lcc}\text { Terapi fisik untuk membantu } \\
\text { dalam kontrol gerakan anggota } \\
\text { tubuh. }\end{array}$ \\
\hline PT6 & $\begin{array}{l}\text { Terapi dengan menggunakan obat- } \\
\text { obatan. }\end{array}$ \\
\hline PT7 & Menerapkan latihan sensorimotor. \\
\hline PT8 & $\begin{array}{l}\text { Terapi fisik dalam mengontrol } \\
\text { ketahanan pergerakan tubuh. }\end{array}$ \\
\hline PT9 & $\begin{array}{l}\text { memerlukan pendekatan lintas } \\
\text { disiplin, termasuk perawatan medis } \\
\text { yang teratur; fisik, okupasi dan } \\
\text { terapi wicara, dan akademis, sosial } \\
\text { dan pelayanan kejuruan. } \\
\text { Kebutuhan untuk tingkat } \\
\text { perawatan dan dukungan tidak } \\
\text { berakhir sebagai anak-anak } \\
\text { menjadi lebih tua dan biasanya } \\
\text { diperlukan sepanjang hidup. }\end{array}$ \\
\hline PT10 & $\begin{array}{lrr}\text { memaksimalkan kemampuan dari } \\
\text { pasien dengan sindrom Rett (RS) } \\
\text { membutuhkan } & \text { penerapan } \\
\text { pendekatan } & \text { tim } & \text { yang } \\
\text { komprehensif. } & & \end{array}$ \\
\hline PT11 & stimulasi saraf vagal. \\
\hline PT12 & $\begin{array}{l}\text { Sukar berpikir abstrak dan terikat } \\
\text { dengan lingkungan. }\end{array}$ \\
\hline PT13 & $\begin{array}{l}\text { Melakukan pembelajaran dengan } \\
\text { konsep permainan ringan. }\end{array}$ \\
\hline PT14 & $\begin{array}{l}\text { Terapi dalam Mengembangkan } \\
\text { keterampilan dasar belajar di } \\
\text { sekolah meliputi, membaca, } \\
\text { menulis, matematika. }\end{array}$ \\
\hline PT15 & $\begin{array}{l}\text { Terapi dalam Mengembangkan } \\
\text { kebiasaan hidup sehat. }\end{array}$ \\
\hline PT16 & $\begin{array}{l}\text { Dapat dilatih dengan mengerjakan } \\
\text { sesuatu seperti } \\
\text { mengerjakan soal dengan konsep } \\
\text { permainan secara rutin. }\end{array}$ \\
\hline PT17 & $\begin{array}{l}\text { Dapat dilatih berkawan secara } \\
\text { perlahan-lahan. }\end{array}$ \\
\hline PT18 & $\begin{array}{l}\text { mengikuti pembelajaran dalam } \\
\text { kegiatan dan menghargai hak milik } \\
\text { orang lain. }\end{array}$ \\
\hline PT19 & $\begin{array}{l}\text { Melatih motorik anak melalui } \\
\text { gerakan dalam permainan. }\end{array}$ \\
\hline
\end{tabular}

\begin{tabular}{|c|c|}
\hline PT20 & $\begin{array}{l}\text { Mengarahkan energi } \\
\text { berlebihan pada anak yang } \\
\text { hiperaktif, menjadi lebih terarah } \\
\text { dan efektif. }\end{array}$ \\
\hline PT21 & $\begin{array}{l}\text { Melakukan Membentuk sikap } \\
\text { tubuh yang baik. }\end{array}$ \\
\hline PT22 & Melatih konsentrasi anak. \\
\hline PT23 & $\begin{array}{l}\text { Melatih anak untuk mampu } \\
\text { mengendalikan emosi. }\end{array}$ \\
\hline PT24 & $\begin{array}{l}\text { Melatih kepedulian anak pada } \\
\text { lingkungan sekitarnya. }\end{array}$ \\
\hline PT25 & $\begin{array}{l}\text { Menggunakan alat bantu dengar } \\
\text { untuk meningkatkan ketajaman } \\
\text { daya pendengarannya. }\end{array}$ \\
\hline PT26 & $\begin{array}{l}\text { memerlukan latihan membaca } \\
\text { bibir untuk pemahaman } \\
\text { percakapan. }\end{array}$ \\
\hline PT27 & $\begin{array}{l}\text { Menggunakan alat bantu dengar } \\
\text { untuk membantu ketajaman } \\
\text { pendengarannya. }\end{array}$ \\
\hline PT28 & Latihan bicara artikulasi. \\
\hline PT29 & Latihan kosakata \\
\hline PT30 & Latihan pendengaran. \\
\hline PT31 & $\begin{array}{l}\text { Perlu pelatihan pendengaran } \\
\text { intensif. }\end{array}$ \\
\hline PT32 & $\begin{array}{l}\text { Latihan membaca bibir / gerak } \\
\text { mulut. }\end{array}$ \\
\hline PT33 & Latihan pembentukan kosakata. \\
\hline PT34 & $\begin{array}{l}\text { Menggunakan alat bantu dengar } \\
\text { atau tidak dalam belajar bicara } \\
\text { atau bahasanya. }\end{array}$ \\
\hline PT35 & $\begin{array}{l}\text { Latihan membentuk dan membaca } \\
\text { ujuran dengan menggunakan } \\
\text { metode-metode pengajaran yang } \\
\text { khusus seperti tactile kinestetic, } \\
\text { visualisasi yang dibantu dengan } \\
\text { segenap kemampuan inderanya } \\
\text { yang tersedia. }\end{array}$ \\
\hline PT36 & $\begin{array}{l}\text { Latihan Penguasaan braille yang } \\
\text { dimaksud adalah kemampuan } \\
\text { untuk menulis dan membaca } \\
\text { braille. Keterampilan menulis } \\
\text { berkaitan dengan penggunaan alat } \\
\text { tulis braille, yaitu reglet, mesik } \\
\text { ketik braille; penulisan huruf, } \\
\text { angka, kombinasi angka dan huruf, } \\
\text { dan komputer braille, sedangkan } \\
\text { membaca lebih berkaitan dengan } \\
\text { keterampilan membaca dari } \\
\text { berbagai media tulisan. }\end{array}$ \\
\hline PT37 & $\begin{array}{l}\text { Latihan orientasi dan mobilitas } \\
\text { adalah jalan dengan pendamping } \\
\text { awas, latihan jalan mandiri, latihan } \\
\text { jalan dengan menggunakan alat } \\
\text { bantu jalan (tongkat dan sign } \\
\text { guide). }\end{array}$ \\
\hline PT38 & Perlu tongkat untuk berjalan. \\
\hline
\end{tabular}




\begin{tabular}{|c|c|}
\hline PT39 & $\begin{array}{l}\text { Memerlukan sarana baca dengan } \\
\text { huruf Braille, radio dan pustaka } \\
\text { kaset. }\end{array}$ \\
\hline PT40 & Harus memakai alat non visual. \\
\hline PT41 & $\begin{array}{l}\text { Penggunaan alat bantu dalam } \\
\text { pembelajaran berhitung dan } \\
\text { matematika, meliputi cubaritma, } \\
\text { papan taylor frame, abacus } \\
\text { (sempoa) dalam operasi } \\
\text { penambahan, pengurangan, } \\
\text { perkalian, pembagian, dan } \\
\text { beberapa komsep matematikan } \\
\text { braille. }\end{array}$ \\
\hline PT42 & $\begin{array}{l}\text { Pembelajaran pendidikan jasmani } \\
\text { bagi anak tunanetra menggunakan } \\
\text { pendidikan jasmani adaftif. } \\
\text { Adaftasi yang dilakukan berkaitan } \\
\text { dengan jenis kecacatan anak, } \\
\text { kemampuan fisik anak, dan } \\
\text { memodifikasi sarana dan prasarana } \\
\text { olah raga meliputi ukuran } \\
\text { lapangan/lintasan, alat yang } \\
\text { digunakan dalam olah raga, dan } \\
\text { aturan yang dipakai. }\end{array}$ \\
\hline PT43 & $\begin{array}{l}\text { Mengunakan PlayerDigital } \\
\text { Ascesible System (DAISY)Player. } \\
\text { DAISY Player digunakan untuk } \\
\text { mempermudah penyandang } \\
\text { tunanetra untuk memperoleh } \\
\text { informasi dari buku tertentu yang } \\
\text { telah diubah menjadi bentuk suara. } \\
\text { Kecepatan dan volume suara dapat } \\
\text { diatur sedemikian rupa sesuai } \\
\text { kebutuhan. Buku bicara yang } \\
\text { digunakan untuk DAISY player ini } \\
\text { berupa compact disk. }\end{array}$ \\
\hline PT44 & $\begin{array}{l}\text { Mengunakan Digital talking books } \\
\text { adalah perangkat yang } \\
\text { memungkinkan pembaca tidak } \\
\text { hanya bisa menikmati suara audio } \\
\text { yang dibacakan dari buku, namun } \\
\text { juga memungkinkan pengguna } \\
\text { untuk melewati beberapa teks } \\
\text { untuk mencari topik atau pencarian } \\
\text { kata tertentu. }\end{array}$ \\
\hline $\mathrm{P} 45$ & $\begin{array}{l}\text { Melakukan Program Pembinaan } \\
\text { Gerakan Tubuh. }\end{array}$ \\
\hline $\mathrm{P} 46$ & $\begin{array}{l}\text { Melakukan Aktifitas } \\
\text { Pengembangan Mobilitas. }\end{array}$ \\
\hline $\mathrm{P} 47$ & $\begin{array}{l}\text { Pembelajaran dalam pemahaman } \\
\text { kesadaran gerak. }\end{array}$ \\
\hline $\mathrm{P} 48$ & $\begin{array}{l}\text { Mengembangkan konsep tentang } \\
\text { gambaran tubuh. }\end{array}$ \\
\hline $\mathrm{P} 49$ & $\begin{array}{l}\text { Mengembangkan ekspresi gerakan } \\
\text { bebas dan eksplorasi terhadap } \\
\text { berbagai gerakan yang dapat } \\
\text { dilakukan. }\end{array}$ \\
\hline P50 & $\begin{array}{l}\text { Melakukan metode terapi fisik } \\
\text { Membantu dalam memposisikan }\end{array}$ \\
\hline
\end{tabular}

\begin{tabular}{|l|l|}
\hline & tubuh dan pola-pola gerakan. \\
\hline P51 & $\begin{array}{l}\text { Mencari alat bantu atau prothese } \\
\text { yang akan membantu meringankan } \\
\text { hambatan yang disebabkan oleh } \\
\text { kenetraannya. }\end{array}$ \\
\hline P52 & $\begin{array}{l}\text { Menerapkan pola pembelajaran } \\
\text { yang khusus serta menjadikannya } \\
\text { sebagai media pembelajaran yang } \\
\text { efektif bagi penyandang tunanetra. }\end{array}$ \\
\hline P53 & $\begin{array}{l}\text { Latihan bicara fisioterapi, } \\
\text { Occupational Therapy dan Hydro } \\
\text { Therapy. }\end{array}$ \\
\hline
\end{tabular}

\section{Penerapan Metode Forward Chaining}

Penelitian ini dibangun penelusuran menggunakan metode forward chaining, Langkah -langkah penelusuran dengan forward chaining (Setojo, T, And dkk. 2011).

Langkah 1: memberikan pertanyaaan ke user

Langkah 2 : menampung inputan dari user berdasarkan sebagai fakta yang diketahui pada short terma memory yang disimpan pada tiap variable pertayaan

Langkah 3 : memeriksa rule berdasarkan fakta pada short term memory dengan metode forward chaining

Langkah 4 : jika rule ditemukan maka konklusi rule ditampung pada short term memory, apabila ada fakta baru maka langkah satu sampai dengan langkah empat diulang. Jika rule tidak ditemukan maka diberikan defult output

Langkah 5 : solusi

Tabel 5 Data Rule Inferensi

\begin{tabular}{|l|l|l|}
\hline Rule & \multicolumn{1}{|c|}{ Kode Gejala } & \multicolumn{1}{c|}{ Kd } \\
\hline R1 & $\begin{array}{l}\text { G1,G2,G3,G4,G5,G6,G7, } \\
\text { G8,G9 }\end{array}$ & JG1 \\
\hline R2 & G10,G11,G12,G13 & JG2 \\
\hline R3 & $\begin{array}{l}\text { G14,G15,G16,G17,G18,G } \\
19, G 20\end{array}$ & JG3 \\
\hline R4 & $\begin{array}{l}\text { G21,G22,G23,G24,G25,G } \\
26, G 27, G 28, G 29\end{array}$ & JG4 \\
\hline R5 & G30,G31,G32,G33 & JG5 \\
\hline R6 & G34,G35,G36,G37,G38 & JG6 \\
\hline R7 & G39,G40,G41,G42,G43 & JG7 \\
\hline R8 & $\begin{array}{l}\text { G44,G45,G46,G47,G48,G } \\
49\end{array}$ & JG8 \\
\hline R9 & G50,G51,G52,G53 & JG9 \\
\hline
\end{tabular}




\begin{tabular}{|l|l|l|}
\hline R10 & $\begin{array}{l}\text { G54,G55,G56,G57,G58,G } \\
59\end{array}$ & JG10 \\
\hline R11 & $\begin{array}{l}\text { G60,G61,G62,G63,G64,G } \\
65\end{array}$ & JG11 \\
\hline R12 & $\begin{array}{l}\text { G66,G67,G68,G68,G69,G } \\
70\end{array}$ & JG12 \\
\hline R13 & $\begin{array}{l}\text { G71,G72,G73,G74,G75,G } \\
76, G 77, G 78\end{array}$ & JG13 \\
\hline
\end{tabular}

Pada table 3.5 adalah rule rule yang didapat berdasarkan gejala-gejala yang ada.

\section{Perancangan sistem \\ Use Care Diagram}

Use case diagram pada gambar berikut menggambarkanapa yang sedang dilakukan oleh seorang actor. Pada perancangan sistem berbasis pengetahuan memiliki actor, yaitu user. Adapun actor tersebut berinteraksi dengan sistem melalui fungsi-fungsi yang dimiliki oleh sistem. Pakar akan menginputkan knowledge base (basis pengetahuan) dan sistem akan menampilkan gejala gangguan.

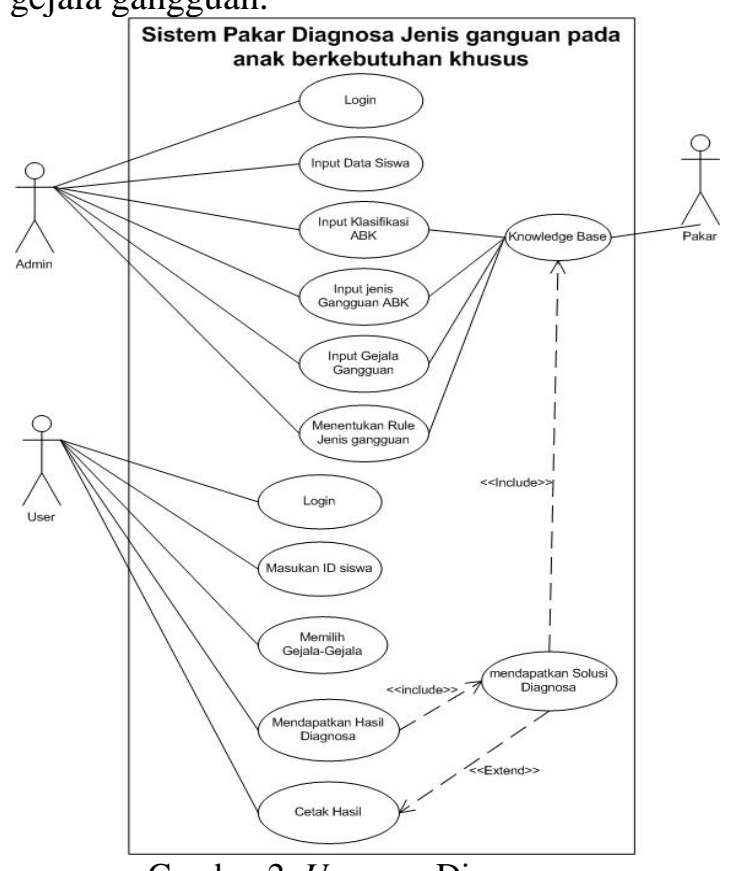

Gambar 2. Use case Diagram

\section{Activity Diagram}

Activity diagram dalam penelitian ini dapat dilihat dari gambar 2.

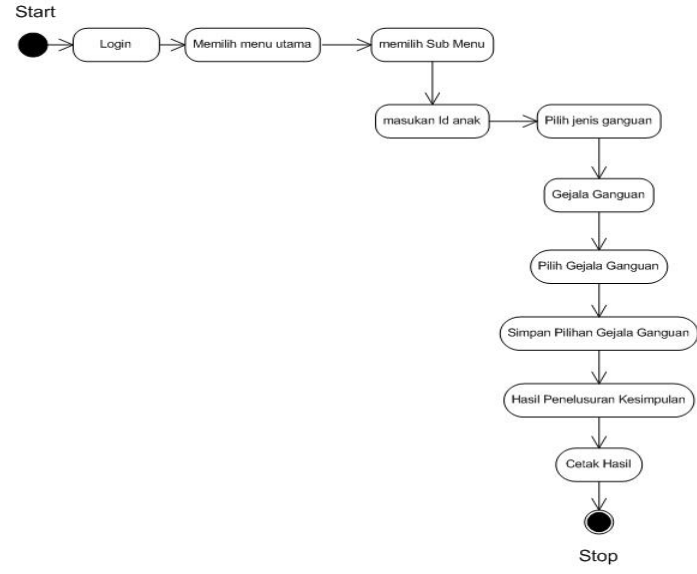

Gambar 3. Activity Diagram

\section{Squence Diagram}

Sequence diagram menggambarkan urutan aktifitas yang dilakukan oleh pengujung menggunakan system berbasis pengetahuan untuk mendiagnosa jenis gangguan anak berkebutuhan khusus, sebelum melakukan pengecekan diwajibkan pengunjung mengisi data-data terlebih dahulu, setelah itu akan masuk kehalaman analisa gangguan, kemudiaan dilakukan analisa maka system akan menampilkan hasil dari analisa yang terdiri dari jenis abk, gangguan, gejala, dan pengendalian dan terapi. Admin juga dapat masuk kedalam system melalui menu admin utnuk melakukan Update Knonladwe base, dan sebelum masuk admin terlebih dahulu harus memasukan ID dan Password yang dimiliki, dan apabila telah selesai update Knowladge base admin dapat keluar dari system dengan memilih Log Out.

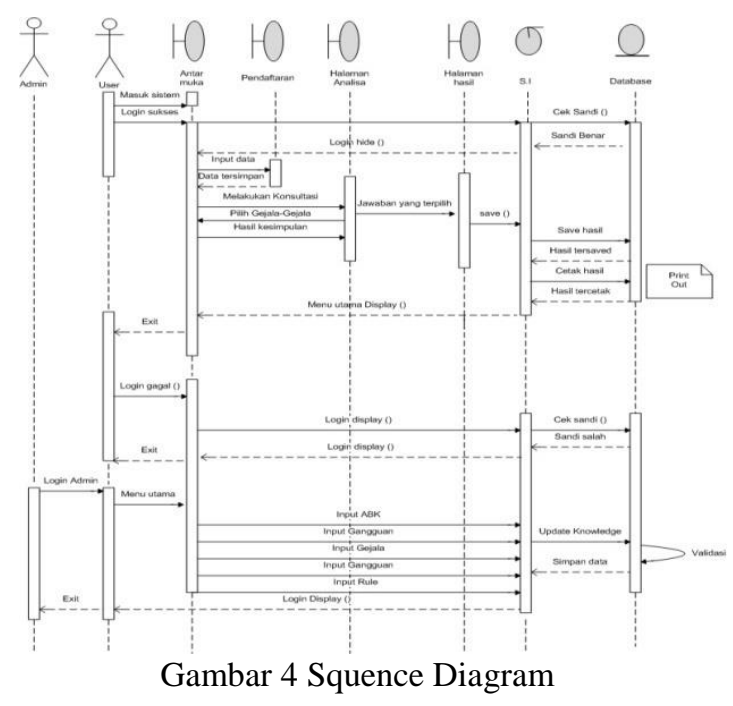




\section{IMPLEMENTASI SISTEM} Rancangan form menu utama

Rancangan software ini digunakan untuk tenaga pengajar guna menentukan kelas bagi anak anak berkebutuhan khusus secara tidak langsung dengan seorang pakar. Software ini merupakan bantuan bagi para tenaga pengajar yang awam serta sebagai acuan untuk menyamakan pendapat tenaga pengajar. Desain antar muka dirancang untuk penghubung antara user dengan sistem pada software penempatakan kelas untuk anak berkebutuhan khusus. desain interface nya dapat dilihat pada gambar dibawah ini:

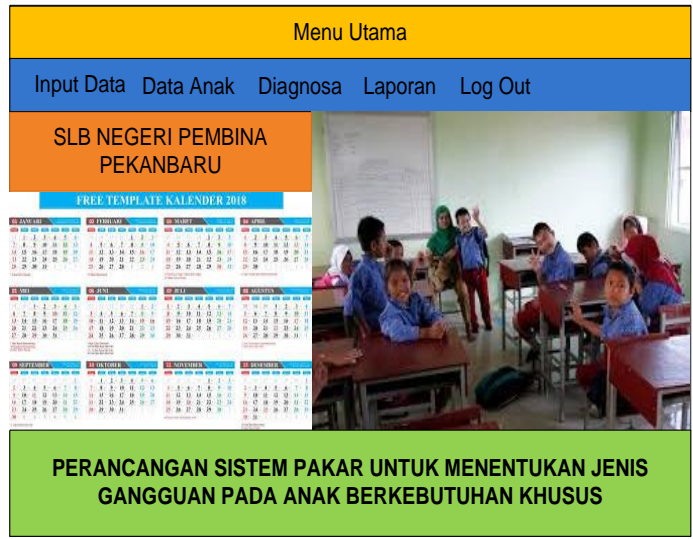

Gambar 5. Tampilan menu utama

Penelusuran diagnose merupakan tampilan dimana pemakai / user dapat memilih dan menjawab pertanyaan berdasarkan gejalagejala yang tampak. Berikut tampilan rancangan menu diagnose/konsultasi

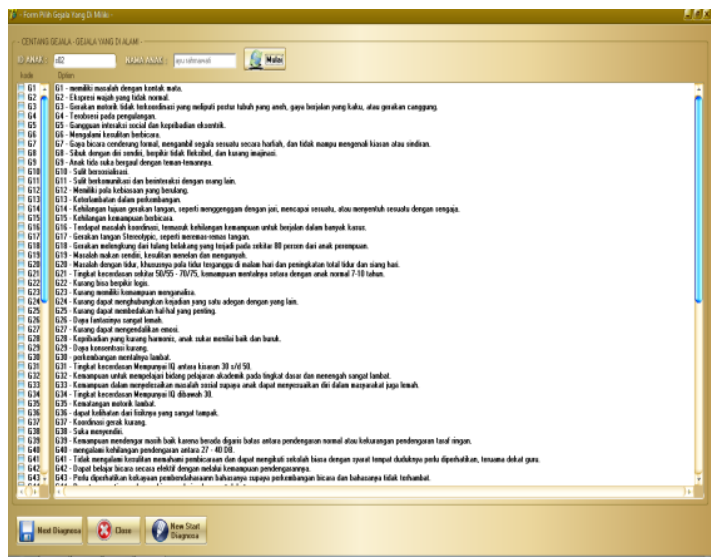

Gambar 6. Tampilan form penelusuran diagnose

Tampilan hasil penelusuran dari diagnosa merupakan tampilan hasil dari diagnosa/ gangguan yang dialami oleh

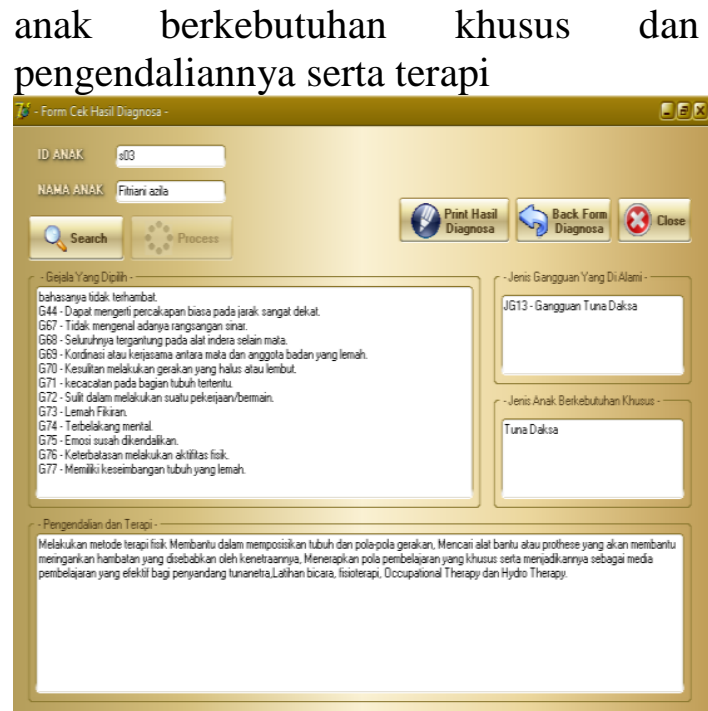

Gambar 7 Tampilan hasil penelusuran diagnose

\section{SIMPULAN}

Kesimpulan yang dapat diambil dari penelitian ini adalah sebagai berikut : Sistem dapat memberikan informasi dengan cepat dan tepat untuk menentukan gangguan perkembangan anak berkebutuhan khusus berdasarkan gejala gejala yang tampak. Penggunaan metode inferensi forward chaining dalam mencari secara tidak langsung, dapat diterapkan pada pembuatan sistem pakar untuk menentukan jenis gangguan pada anak berkebutuhan khusus. Tingkat keakuratan dari sistem tergantung knowledge base yang tersimpan dalam database

\section{UCAPAN TERIMAKASIH}

Terima kasih penulis ucapkan kepada Sekolah SLB Negeri Pemina Pekanbaru yang telah membantu penulis untuk memberikan data serta kepada Lemabaga Penelitian dan Pengabdian Masyarakat (LPPM) STIKOM Pelita Indonesia atas dukungan moril.

\section{DAFTAR PUSTAKA}

A, Kristianto, 2004."Artificial Intelligence (Kecerdasan Buatan)", Yogyakarta:Graha Ilmu.

Harto, Dodi (2013),"Perancangan Sistem Pakar Untuk Mengidentifikasi Penyakit pada Tanaman Semangka Dengan Menggunakan Metode Certainty Factor 
(CF)",Pelita Informatika Budi Darma Volume IV, Nomor 2.

http://id.wikipwdia.org/wiki/anakberkebut

Kusumadewi, S (2003), "Artificial Intelligence(AI) Teknik dan Aplikasinya. Yogyakarta, Andi Offset. Kusrini, 2006, "System Pakar Teori dan Aplikasi. Yogyakarta, Andi Offset.

Marcin, Ochab, W. W. (2016),'Expert System Supporting an Early Prediction of The Brockhopulmonary dysplasia, computers in biologhy and medicine, 236-244.

M. Arhami, (2005). "Kecerdasan Buatan"

Rohman, F, Feri, Fauzijah Ami, (2008),"'Rancang Bangun Aplikasi System Pakar Untuk Menentukan Jenis Gangguan Perkembangan Pada Anak", Media Informatika, Vol. 6 No 1, Juni 2008, 1-23, ISSM:0854-4743.

Setojo, T, And dkk. (2011), Kecerdasan Buatan, Yogyakarta, Indonesia:Unidus

William P.Wagner. (2017). "Trens in Expert System Development: A Longitudinal Content Analysis of Over Thirty Yeasrs of Expert System case Studies".Wxpert System Whit Application,85-96.

Yanto. F, Bagus, And dkk, (2017).”Aplikasi system pakar diagnose penyakit anak bawah lima Tahun Menggunakan Metode Fordward Chainig". Journal of Information System Engineering and Business Intelligence",Vol.3 No 1 April. 